\section{Kovalenko M., \\ Ziuz D. \\ Nakisko 0., \\ Rudenko S. \\ Ryzhikova $\mathbf{N}$.}

\title{
IMPROVEMENT OF THE EMISSIONAL COMPONENT OF THE BANKING SYSTEM AS THE FACTOR OF ACTIVATION OF THE INVESTMENT PROCESS
}

Об’єктом дослідження є банківсъка система, спрямована на підтримку інвестиційних процесів національної економіки Украйни. Перспективним постає проведення дослідження щодо розробки пропозищій скорішого реформування банківської системи. Ця система повинна забезпечити національну економіку необхідним обсягом внутрішніх інвестищій, спрямованими на стимулювання розвитку високотехнологічних галузей та значне збільшення випуску продукцї з високою доданою вартістю, здійснення розвитку імпортозамінних виробнищтв, підвищення зайнятості населення тощо.

В ході дослідження використовувався міждисциплінарний підхід до вивчення зовнішніх факторів впливу та інститутів здійснення емісійної політики з боку банківської системи на засадах організації змішаного типу економічної системи, спрямованих на:

- стимулювання розвитку реального сектора економіки;

- підвищення якості цільового використання кредитних коштів;

- оптимізацію міжбюджетних відносин;

- зміцнення фінансової спроможності підприємств;

- перехід роботи банківської системи до інноваційних форм функціонування;

- залагодження зовнішніх та внутрішніх викликів;

- активізацію інвестиційних процесів на підприємствах національної економіки України.

Запропоновані заходи щодо вдосконалення емісійної політики з боку Національного банку (рефінансування) та комериійних банків (кредитування), орієнтовані на цільове фінансування інвестицій в реальний сектор національної економіки. Має відбутися кардинальна зміна інституційної ролі банківської системи України. Гроші, емітовані банківською системою, під пильним керівнищтвом держави мають спрямовуватися на реалізацію інвестиційних проектів народного господарства, де вони матеріалізуються $і$ підкріплюються новоствореною виробленою продукцією. Завдяки цььому забезпечується широка підтримка власного сучасного виробнищтва, що спрямована на виробнищтво продукції з високою доданою вартістю та має забезпечити населення гідними робочими місиями та заробітною платою. Все це надасть можливість підвищити суверенність держави, максимально мобілізують наявний ресурсний потенціал економіки, сприятиме скорішому переходу на новий техніко-економічний уклад, заснований на інноваційно-інвестиційному суспільному відтворенні.

Ключові слова: банківська система, емісія грошей, внутрішній кредит, інвестиційний процес, національна економіка, соціально-економічний розвиток, публічне управління.

\section{Introduction}

The banking system of Ukraine over the past decade has separated into a special contour of public reproduction, increasingly becoming a business for the elect. Practically not demanding capital-intensive investments, technological use or processing of resources in the production sphere, the banking sphere is increasingly becoming a virtual business, the interest in factors of the real process of reproduction and the necessary institutional provision is weakening. More and more revenues are generated from the provision of services based on usury and speculation. Ukrainian banking business has recently acquired the form of monopolies, interconnected with supranational capital and state power. The enthusiasm for monetary regulation of the Ukrainian economy led to a loss of investment capacity on the part of the state and Ukrainian entrepre- neurship, the transformation of the national economy to the colonial type of the sectoral structure of the economy.

Thus, it is topical to conduct a study on developing proposals for early reform of the banking system that could provide the domestic economy with the necessary amount of domestic investment aimed at:

- stimulating the development of high-tech industries and

a significant increase in output with high added value;

- development of import-substituting industries;

- increase of employment of the population, etc.

\section{The object of research and its technological audit}

The object of research is the banking system aimed at supporting the investment processes of the national economy of Ukraine. 
In economic literature, it is quite often possible to find such notion as the «banking system». There are many definitions of the essence of the banking system, the general meaning of which is that the banking system is a set of banks, institutions in their interrelations that are combined and functions as a result of the activities of the state and society. The banking system of Ukraine consists of the National Bank of Ukraine (NBU) and other banks, as well as branches of foreign banks that are established and operate on the territory of Ukraine in accordance with the provisions:

- The Law on Banks and Banking Activities;

- The Law «On the National Bank of Ukraine»;

- The Law «On Financial Services and State Regula-

tion of Financial Services Markets» and other laws of Ukraine.

In the modern economy, the main pillar of the financial system is the banking system. It issues money (cash and non-cash), concentrates and directs private savings, mobilizes public finances in certain areas of development of the national economy, distributes investments among enterprises, takes part in optimizing the balance of consumption of households and enterprise expenses in a time dimension, allows the latter to distribute risks and the like. At the same time, one of the little-studied issues in the sphere of organizing the banking system is the increase in the investment potential of the banking system aimed at modernizing the national economy.

\section{The aim and objectives of research}

The aim of research is substantiation and development of methodological bases for the organization of the issuing activity of the banking system of Ukraine, which can ensure the effective functioning of domestic credit as a factor in accelerating the investment processes of the national economy.

To achieve this aim, the following objectives are defined:

1. To provide a description and an analysis of existing approaches to organizing monetary support for domestic investment of the national economy.

2. To identify areas for improving the issuing policy of the banking system, as a factor in the activation of investment processes in Ukraine.

\section{Research of existing solutions of the problem}

To ensure the necessary level of domestic investment of the national economy, it is the banking system that realizes its possibilities with respect to the sovereign right to issue money through the organization of domestic (national) credit. In this process, both the NBU (refinancing of commercial banks) and commercial banks (direct lending to business entities) participate.

The official website of the NBU notes that the procedure for issuing money is strictly regulated and implemented by the central bank through the currency, stock and credit channels and is ensured by the receipt by the NBU of an equivalent volume of foreign currency or liquid financial instruments. If necessary, the withdrawal of money from circulation also takes place through these channels [1].

But according to the functional features of the money itself, the money issue, in its majority, should not be co- vered by the amount of foreign currency or liquid financial instruments, and first of all the newly created products. This can be achieved through the use of a special credit channel - refinancing of specialized state-owned banks. Such loans can be non-interest-bearing and targeted at targeted financing of the real sector of the economy. The latter, fundamentally different from the practice of the NBU, because the policy of this body is constantly moving in line with high interest rates for active and passive operations, as, as of February 13, 2013. The corresponding rate was $18 \%$ [2]. This does not allow creating new ones and maintaining existing production capacities, because it is more than the rate of return of many typical manufacturing enterprises.

Recently, it is rightly noted that at the present time central banks, by regulating interest rate inflation, with its increase, generate a high level of unemployment and a decrease in the purchasing power of wages. Accordingly, such monetary policy does not ensure social justice [3].

According to the Keynesian approach, the slowdown in the growth of the money supply leads to the fact that fewer goods and services are produced, fewer jobs are created. The economic system, according to representatives of the Keynesian approach, should produce as much production as possible and provide the maximum possible employment, as far as it is compatible with moderate inflation rates [4]. The interest rate does not automatically adjust to the level that most corresponds to the public good, but constantly seeks to rise very high, and the «wise» government should take care to reduce it, taking into account the laws, customs and even the moral values of society [5]. The real evil for society is the violation of spiritual laws in the conduct of economic activity. First of all, this relates to our fall into the law of legalization and the promotion of the usurious interest and parasitism, which ideologically is supported by ordinary idolatry and the money thus performs the role of an idol [6].

Representatives of the monetarist approach argue that if the growth in the supply of money will be limited to a value corresponding to the growth of real GDP, then inflation can be virtually eliminated. That is, the supply of money should increase in accordance with the growth in real GDP [4].

However, the amount of money is limited only by the possibilities of the economy. Money is an instrument that drives economic activity to produce goods and services. This is the so-called stimulating function of money, in which money becomes an incentive to manifest intentions regarding production and consumption. The implementation of this function allows the state to be economically sovereign and to ensure the mobilization of all the factors of production available to it for the its long-term socio-economic development. Thus, money becomes not just a link in the economy, on the contrary, they play a huge role, driving production and consumption. It is on this understanding of the quantitative theory of money in conditions of ensuring effective demand that Keynesianism insists: «As long as there is incomplete employment of the factors of production, the degree of their use will vary in the same proportion as the amount of money; if their full employment is achieved, the prices will change in the same proportion as the amount of money» [5].

The experience of countries achieves rapid social and economic development, testifies to the need for an integ- 
rated approach to the formation of a money supply based on internal sources of monetary emission and its linkage to the implementation of state targeted programs. These programs are aimed at solving the most important problems of the development of society. The first of such sources of money issue is the instrument of refinancing of banking institutions. But provided that such emission is limited exclusively to lending to the real sector of the economy and investing in priority areas of its development. This can be achieved only if the current banking system of Ukraine is transformed.

A study of the actions of the central banks of countries with developing market economies evidences the absence of their systemic influence on the development of the economy [7, 8]. They focus on short-term problems of price stability, the exchange rate, interest rates and do not take into account the macroeconomic problems of the national economy associated with the loss of productive capacity of the real sector of the economy and negative structural «distortions» of the economy. At the same time, the cost of credits becomes prohibitively large, which leads to a bleeding of production, an increase in the cost of production, and, consequently, of prices.

The banking system should become a key component of the innovation-investment model of social reproduction. As a lender, among innovative projects the bank independently chooses the most attractive objects from both economic and social points of view; simultaneously acts as the supervising body and the coordinator of projects, monitors the effectiveness and targeted use of funds. The conducted researches show that the investment activity of banks should be coordinated with the tasks of structural reorganization of the national economy, the priority directions of innovation activity, determined by the legislation $[9,10]$.

An obstacle to attracting the banking system's ability to organize issuing activities that can provide the necessary level of investment processes in Ukraine is the inconsistency of monetary and budgetary policies based on the NBU's controversial position regarding its independence from the executive and legislative powers [11-13]. The society must be confident that the National Bank is pursuing precisely the policy that best suits its interests, contributes to the country's social and economic growth. One of the means to achieve this is the so-called information transparency of the NBU before society, it must be guaranteed by the system of organizational counterbalances, introduction of state banking control by public authorities.

\section{Methods of research}

During the execution of the work general scientific and special research methods are applied:

- analysis and synthesis - to form the problem and determine goals, assumptions and risks for improving the issuing policy of the banking system;

- the abstract-logical method is used to determine the structure of work and the design of the research, to provide suggestions for improving the issuing policy of banking policy with a view to the speedy transformation of the national economy to the innovation-investment model of social reproduction;

- the use of the laws of universal organizational science (tectology), one of which (the law of the least) is determined that the stability of the equilibrium of organizational forms. For example, such as the management of the financial system of the country, is limited by the strength of the weakest link - the management of the banking system, is of particular importance for the implementation of investment projects on the scale of the entire national economy of Ukraine;

- analogies and comparative comparisons - to determine the characteristics of the activation of domestic emissions and increase the capacity of domestic credit for business entities, the involvement of banking institutions in the implementation of the program-target method by public authorities.

\section{Research results}

Analysis of the money supply of the Ukrainian economy shows the loss of sufficient conditions for replenishment of money in circulation to satisfy the basic economic processes of the society that Ukraine had at the stage of becoming its statehood, further failure and too slow growth. To restore the previous positions on increasing the optimal quantity and quality of the money supply, the entire history of the National Bank's functioning has not been achieved. The optimal amount for the Ukrainian economy should be the amount of money that can provide for the state the opportunity, first of all, to tap the entire resource potential of Ukraine (labor, natural, material, etc.). It is necessary to ensure structural modernization of the economy. An important question arises, the realization of a model in which a process of restoring productive forces and production relations could take place on a permanent basis [14].

When forming monetary policy, the National Bank together with the profile ministries should assess the macroeconomic consequences of hryvnia emission through different channels:

- to refinance commercial banks for the obligations of manufacturing enterprises;

- for government bonds and development institutions for the purpose of implementing state targeted programs;

- for replacing foreign-currency loans;

- for the purchase of foreign currency to accelerate the modernization of manufacturing enterprises and the like.

Under such conditions, leadership should receive an interest-free form of lending from state-owned banks. Private banks, rather, will have to shift their earnings towards receiving a fee (commission) for the services they provide (payments, customer accounts, etc.). And also by crediting the real sector of the economy on the basis of the distribution between the lender and the borrower as future profits and risks.

Another factor that will allow increasing investments in the real sector of the economy is the introduction of payments to banking institutions from the side of depositors for servicing their deposit accounts. Then each person decides for themselves that it is more profitable for them to keep money on deposits, paying a certain amount for it, or, nevertheless, it is better to invest them in entrepreneurial business and further profit.

Under such conditions, the banking system of Ukraine, which is absolutely different in its functional content, should be formed, which will be aimed at providing the 
level of investment necessary for the development of the economy. Under such system, the NBU becomes a chain of the national state management system, the real power over which is returned from the IMF and corporate lobbies to the Cabinet of Ministers of Ukraine. It is composed not of politically engaged amateurs and compradors, but of real experts and statists. Of course, this should be preceded by the present separation of oligarchic clans from state administration.

Let's determine the amount of money supply by the banking system, which would allow the economy to grow and not provoke inflationary processes. Inflation is understood as the rise in prices caused by an excessive increase in the amount of money circulating in the country, and this increase far exceeds the needs of economic activity [3].

Fig. 1 shows the growth in demand $\left(D \rightarrow D^{\prime}\right)$ after the «n» of the sum of new money enters economic turnover.

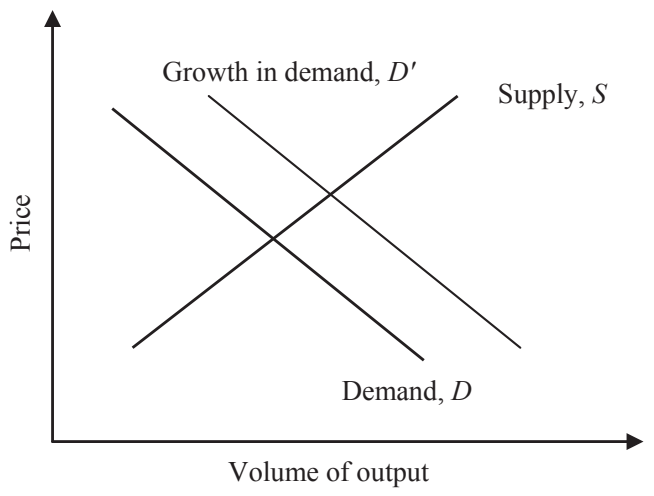

Fig. 1. Growth in demand $\left(D \rightarrow D^{\prime}\right)$

The growth in demand will be due to the flow of credit funds provided for the creation of a particular production facility, to end users by:

- payment of wages (for the performance of a certain amount of work);

- profit by physical/legal entities (for goods and services delivered by them);

- budgetary redistribution (tax revenues to budgets of various levels), etc.

Thus, some change in the money supply (depending on the volume of attraction of free resources mobilized within the national economy) stimulates the economic activity of entrepreneurs to produce more goods and services. Entrepreneurs are so used to seeing in the growth of cash proceeds from the sale of goods, a signal to expand production, they can continue to act this way even when it practically ceases to be profitable for them [5].

Under such conditions, there will be an increase in supply $\left(S \rightarrow S^{\prime}\right)$, which will be compared to demand $\left(D^{\prime}\right)$ (Fig. 2).

But in the market there can be a situation in which a certain amount of goods will not be covered by the money supply (taking into account the speed of circulation of money). Therefore, the following should determine the necessary amount of money, which should again return to the economic turnover and cover the corresponding sentence $S^{\prime}(1)$.

$$
{ }^{*} M=B+K,
$$

where $M$ - the required amount of money to cover the offer; $B$ - the projected total cost of resources and output will be consumed in the domestic market; $K$ - credit funds withdrawn from circulation (returned to banking institutions); * - taking into account the same speed of money circulation.

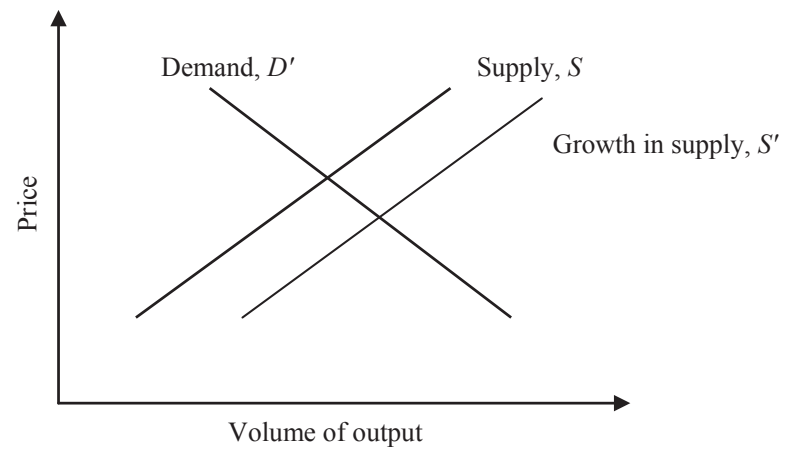

Fig. 2. Growth in supply $\left(S \rightarrow S^{\prime}\right)$

Thus, it is necessary to calculate the projected total cost of resources, it is planned to use it in the production process and products, which will be sold exclusively on the domestic market. It is also necessary to take into account the funds received from the sale of goods sent for export. They, first of all, cut off the import of technologies and high-tech means of production, which are not yet produced within the national economy. The amount of money to cover the offer includes the amount of credit funds returned to the banking system (which were provided for investment projects).

In case of acceleration or slowdown of monetary circulation, the formula for calculating «M» (the necessary amount of money to cover the offer) will be as follows:

$$
\begin{aligned}
& * M^{\prime}=\frac{B+K}{\Delta S}, \\
& * * M^{\prime \prime}=B+K \cdot \Delta S,
\end{aligned}
$$

where $M^{\prime}$ - the necessary amount of money to cover the supply with accelerated monetary circulation; $M^{\prime \prime}$ - the necessary amount of money to cover the proposal with a delayed monetary circulation; $\Delta S$ - the share of the speed of money circulation (the ratio of the base to the predicted velocity of money circulation); ${ }^{* *}$ - taking into account the influence of the speed of rotation of the total amount of funds (in circulation) on the entire national economy, because with its excessive acceleration, it is necessary to reduce this volume and vice versa.

Having found the necessary volume of $\langle M »$, it is necessary to conduct the corresponding issue of money from the banking system, which should ensure the implementation of Ukrainian investment, which in the process of the multiplier effect will fill the gap between supply and demand.

At the same time, the issue of reforming the tax policy and improving the budgetary policy of the state is important. The funds to be received by budgets of various levels should be redistributed by increasing the cost of basic and applied scientific research in the context of the needs of industrial development, an increase in wages. This will serve the formation of effective demand, which in turn will satisfy an ever-growing proposal aimed at providing 
the population with a wide range of goods and services necessary for the development and constant reproduction of the country's human potential.

It should also be noted that the volume of short-term lending by the banking system should be balanced with the long-term, which guarantees a reduction in the risks of creating inflationary processes (this is achieved by improving the quality of budget planning and harmonization of monetary and budgetary policies). At the same time, it is better to have a job with a salary, the purchasing power of which has decreased by several percent, than it does not have at all [15].

To form a banking system that can provide a new emission policy for the country aimed at facilitating the investment processes of the national economy, the following system of measures is proposed:

- change in the status and functional role of the National Bank of Ukraine (NBU) with the simultaneous establishment of state control over the processes of banking regulation and supervision, providing for a weighted system of balances;

- to create and provide a substantial resource potential of state development banks at both the state and regional levels by refinancing them by the National Bank for investment projects approved by the government in accordance with established priority development directions and implemented state targeted programs. To place such loans, state development banks should, on the principles of targeted lending to specific investment projects, providing for the allocation of money exclusively for the expenses they set, without transferring money to the borrower's account;

- regulation of the money supply with the predominance of refinancing of commercial banks on the security of credit requirements of production enterprises, state bonds and development institutions in the implementation of state targeted programs. State development banks should be subject to special conditions that are consistent with the profile and objectives of their activities;

- in order to exclude the stimulation of currency speculation and the export of capital, the National Bank should stop accepting foreign securities and foreign assets from banks operating in the country as collateral for loans;

- to expand the list of collateral for the NBU by including promissory notes and bonds of solvent enterprises operating in priority areas, development institutions (state development banks, innovation and investment funds, development funds, state scientific and commercial corporations of scientific and technical development, etc.), guarantees of the Cabinet of Ministers, regional government bodies;

- to ensure stable credit conditions to prohibit commercial banks from reviewing the terms of loan agreements unilaterally;

- establishment of a fixed exchange rate of the hryvnia with the establishment of previously announced limits of fluctuations in the exchange rate of the hryvnia, which it is important to adhere to for a long time; - state commercial banks to consistently replace loans of business entities in foreign currencies, servicing settlements with domestic counterparties, hryvnia loans with the provision of appropriate support from the NBU;
- introduction in practice of additional norms of banking supervision that contribute to preventing the flow of production emitted from the refinancing of production activities and investment of money into the financial and foreign exchange market;

- to strengthen state supervision over non-bank financial institutions (insurance companies, credit unions, pawnshops, leasing companies, pension funds, investment funds, financial companies) and especially for their currency transactions.

Thus, when proposed measures to improve the issuing policy by the National Bank (refinancing) and commercial banks (lending), focused on targeted financing of investments in the real sector of the national economy, a drastic change in the institutional role of the banking system of Ukraine should take place.

\section{SWOT analysis of research results}

Strengths. Strengths are that the proposed measures to improve the issuing policy of the banking system:

- will ensure the formation of an important component

of the institutional environment for building a just society;

- increase the sovereignty of the state;

- maximally mobilize the existing resource potential of the economy;

- promote an early transition to a new technical and economic structure based on innovative investment public reproduction.

Weaknesses. The conducted research has shown that the introduction of the proposed activities can meet «misunderstanding» on the part of the current system of power, the share of the scientific community and citizens of Ukraine. This is formed under the influence of contradictory ideological cliches on the part of modern economic theory, the values of the consumer society, and the like. At the same time, there is the formation of unproductive information «noises», distractions of the population are completely unnecessary and not even useful for him. In a certain way, one can speak about the importance of active preparation of society for the implementation of the proposed measures by the public administration.

Opportunities. The use of the research results will allow to optimally combine the market mechanism with the state methods of regulation of the economy. This will help to revive industry and high-tech agriculture, to ensure the achievement of a high level of development of research and development work, productive forces; strengthen the social orientation of economic development. Broad support for own modern production, aimed at the production of products with high added value, should provide the population with decent jobs and wages. Change the purpose of the banking system aimed at enhancing the innovation and investment activities of business entities, contribute to a more complete implementation of creative opportunities, own talents for the honest and useful work of every citizen of Ukraine.

Threats. Simultaneously with the introduction of the proposed measures, it is necessary to be prepared for a possible confrontation on the part of those who are the beneficiary of the monetary and credit relations operating in the country and their mercenaries. These are primarily transnational financial corporations, a number of 
interested countries, supranational regulatory structures, internal oligarchic clans and the like. The situation can be complicated by a possible military invasion, the commission of terrorist acts, economic and civil sabotage by a certain part of the population, foreign economic sanctions from the relevant part of the international community.

\section{Conclusions}

1. Characteristic features of the current in the country approach to the implementation of issuance policy by the banking system of Ukraine. Limited funding leads to almost no funding for strategic projects in the country and regions. As practice shows, most of the costs are current and often «urgent». Capital projects, if implemented, only in the construction or repair of socially significant facilities. The majority of projects or investment subventions aimed at supporting physically and morally obsolete basic infrastructure and «stopping holes». Almost does not go on investment projects aimed at the future, indeed the development of measures that would affect the shift in the structure of the economy, its productivity, labor intensity, employment structure or income from active economic activity. The need to change the current issuing policy from the NBU and commercial banks is proved, it can provide stimulating functions to the money, become an incentive to manifest intentions regarding production and consumption. The implementation of this function allows the state to be economically sovereign and to ensure the mobilization of all the factors of production available to it for the sake of its long-term socio-economic development.

2. Directions for improving the issuing policy of the banking system as a factor for activating investment processes in Ukraine have been identified. The triune interaction «state-bank-society» should ensure a positive synergetic effect in facilitating the transition of Ukraine to a postindustrial society, the emergence of its economy on the path of innovative development. A number of measures are proposed to improve the approach of saturation of the economy with money from the banking side for investment projects (re-equipment, expansion or creation of new production capacities). The money emitted by the banking system, under the strict guidance of the state, should be directed to the implementation of investment projects of the national economy, where they materialize and are backed by newly created products.

\section{References}

1. Emisiia hroshei // National Bank of Ukraine. URL: https:// bank.gov.ua/control/uk/publish/article?art id=123306

2. Protsentni stavky za aktyvnymy i pasyvnymy operatsiiamy NBU // National Bank of Ukraine. 2018. URL: https://bank. gov.ua/control/uk/allinfo

3. Stiglitz J. Joseph Stiglitz Says Standard Economics Is Wrong. Inequality and Unearned Income Kills the Economy // Evonomics. 2016. URL: http://evonomics.com/joseph-stiglitz-inequality-unearned-income/
4. Osnovy ekonomichnoi teorii: handbook / ed. by Kozak Yu. H., Shapoval S. S. Kyiv: Tsentr uchbovoi literatury, 2012. 264 p.

5. Keynes J. M. The General Theory of Employment, Interest, and Money. 2011. URL: https://cas2.umkc.edu/economics/ people/facultypages/kregel/courses/econ645/winter2011/generaltheory.pdf

6. Kovalenko M. M. Nove traktuvannia sutnosti ta funktsionalnoho skladu hroshei // Teoriia ta praktyka derzhavnoho upravlinnia. 2015. No. 1 (48). P. 70-78.

7. Turkay M. Heterogeneity across emerging market central bank reaction functions // Central Bank Review. 2017. Vol. 17, No. 3. P. 111-116. doi:10.1016/j.cbrev.2017.06.002

8. Pelin O. G. Does the central bank directly respond to output and inflation uncertainties in Turkey? // Central Bank Review. 2016. Vol. 16, No. 2. P. 53-57. doi:10.1016/j.cbrev.2016.05.001

9. Brinkmeyer $\mathrm{H}$. A new view: Implications of financial innovation for bank lending // Drivers of Bank Lending. 2014. P. 35-43. doi:10.1007/978-3-658-07175-2_4

10.Durham B. Foreign Portfolio Investment, Foreign Bank Lending and Economic Growth // FRB International Finance Discussion Paper No. 757. 2003. 35 p. doi:10.2139/ssrn.382063

11. Kozmenko O., Kuzmenko O. Modeling the stability dynamics of Ukrainian banking system // Banks and Bank Systems. 2013. Vol. 8, No. 2. P. 55-62. doi:10.21511/bbs.8(2).2013.01

12. Kolupaieva I. V., Gavkalova N. L. Deregulation Of The Ukrainian Economy: Problems and Peculiarities of Further Implementation // Horizons international scientific journal. Series A Social Sciences and Humanities. 2016. Vol. 20. P. 389-397.

13. Ukraine. IMF Country Report No. $15 / 69$ // International Monetary Fund. 2015. URL: https://www.imf.org/external/ pubs/ft/scr/2015/cr1569.pdf

14. Kovalenko M. M. «Surrency board» chy «absoliutni hroshi» rabstvo chy volia: proceedings // Publichne upravlinnia XX st: tradytsii ta innovatsii. Kharkiv: KharRI NADU «Mahistr», 2017. P. 378-382.

15. Savchuk N., Grydzhuk D. Modern tendencies of the Ukrainian banking system development // Banks and Bank Systems. 2017. Vol. 12, No. 4. P. 105-113. doi:10.21511/bbs.12(4).2017.10

Kovalenko Mykola, Doctor of Public Administration Sciences, Associate Professor, Department of Economic Theory and Finance, Kharkiv Regional Institute of Public Administration of the National Academy of Public Administration attached to the Office of the President of Ukraine, Ukraine, e-mail: kovnn1@gmail.com, ORCID: https://orcid.org/0000-0003-2845-6993

Ziuz Dmytro, Postgraduate Student, Department of Economic Theory and Finance, Kharkiv Regional Institute of Public Administration of the National Academy of Public Administration attached to the Office of the President of Ukraine, Ukraine, e-mail: 31036@ukr.net, ORCID: https://orcid.org/0000-0002-5825-6696

Nakisko Oleksandr, PhD, Associate Professor, Department of Accounting and Audit, Kharkiv Petro Vasylenko National Technical University of Agriculture, Ukraine, e-mail: Nakisko307@gmail.com, ORCID: http://orcid.org/0000-0003-3789-2455

Rudenko Serhii, PhD, Senior Lecturer, Department of Accounting and Audit, Kharkiv Petro Vasylenko National Technical University of Agriculture,Ukraine, e-mail: oblikua7@gmail.com, ORCID: http:// orcid.org/0000-0002-2874-1957

Ryzhikova Natalia, PhD, Associate Professor, Department of Accounting and Audit, Kharkiv Petro Vasylenko National Technical University of Agriculture, Ukraine, e-mail: goncharenkonat@gmail.com, ORCID: http://orcid.org/0000-0002-3019-8172 